\title{
6. MESOZOIC CALCAREOUS NANNOFOSSILS FROM LEG 130 ${ }^{1}$
}

\author{
Shaozhi $\mathrm{Mao}^{2}$ and Sherwood W. Wise, Jr. ${ }^{2}$
}

\begin{abstract}
The distribution of Mesozoic calcareous nannofossils are tabulated for Holes 807C and 803D drilled on the Ontong Java Plateau in the western equatorial Pacific. Nannofossils were abundant but poorly preserved in Hole $803 \mathrm{D}$ and range from early Albian to Maastrichtian in age. A possibly complete and expanded $\mathrm{K} / \mathrm{T}$ boundary interval yielded few diagnostic taxa because of the dissolution of Tertiary forms. The only nannofossil-bearing sample examined from Hole 803D contained the uppermost Maastrichtian zonal indicator Micula prinsii.
\end{abstract}

\section{INTRODUCTION}

Mesozoic calcareous nannofossils were recovered at two Ocean Drilling Program (ODP) sites drilled on the Ontong Java Plateau in the western equatorial Pacific (Fig. 1). At both sites preservation was poor because of deposition close to the calcite compensation depth and postdepositional diagenesis. Species diversity of the assemblages and stratigraphic resolution were consequently low. As a result, a formal zonation was only applied to the Upper Cretaceous section. Nevertheless, even there it was impossible to delineate all of the zones, subzones, or datums recognized by Sissingh (1977), Roth (1978), or Perch-Nielsen (1979). Instead, broader intervals were delimited based on a restricted number of marker species; the less detailed sequences of datums suggested by Thierstein (1976) and subsequently incorporated into zones by Verbeek (1977) proved to be the most applicable.

The sequences were closely examined by the shipboard nannofossil specialists (J. Backman and T. Takayama), and their reports are given in Kroenke, Berger, Janecek, et al. (1991). Over certain key intervals, their reports are more detailed than ours because of closer sample spacing, and their observations are reported herein where applicable. The main purpose of the present study is to provide details of the assemblages through distribution charts and photomicrographs.

The nannofossils were observed in the light microscope at a magnification of $1560 \times$ using simple smear slide preparations. Their distributions were plotted on range charts in order of their first occurrences (FOs). Relative individual species abundance estimates follow the procedure of Hay (1970) and are indicated in the following manner: V $=$ very abundant $(>10$ specimens/field of view $) ; \mathrm{A}=$ abundant $(1-10$ specimens/field of view); $\mathrm{C}=$ common ( 1 specimen/2-10 fields of view); $\mathrm{F}=$ few $(1$ specimen/11-100 fields of view); and $\mathrm{R}=$ rare $(1$ specimen/101-1000 fields of view). Qualitative estimates of overall nannofossil abundance were given the following letter codes: $V=$ very abundant, $\mathrm{A}=$ abundant, $\mathrm{C}=$ common, and $\mathrm{F}=$ few.

The average state of preservation of nannofossils per sample was designated as follows: $\mathrm{G}=$ good (little or no etching or overgrowth); $\mathbf{M}=$ moderate (some etching and/or overgrowth, identification of species is not generally impaired); and $\mathrm{P}=$ poor (strong etching and/or overgrowth, identification of species is impaired but often still possible). Taxa considered are given in the Appendix, and corresponding bibliographic references for these taxa are provided in Perch-Nielsen (1985a, 1985b).

\footnotetext{
'Berger, W.H., Kroenke, L.W., Mayer, L.A., et al., 1993. Proc. ODP, Sci. Results, 130: College Station, TX (Ocean Drilling Program).

${ }^{2}$ Department of Geology, Florida State University, Tallahassee, FL 32306, U.S.A.
}

\section{SITE DESCRIPTIONS}

\section{Hole 807C}

Hole $807 \mathrm{C}$ was drilled at $3^{\circ} 36.4^{\prime} \mathrm{N}, 156^{\circ} 37.5^{\prime} \mathrm{E}$ in a water depth of $2797 \mathrm{~m}$. Abundant but poorly preserved nannofossils were recovered from 84 samples taken from limestones in Cores 130-807C-54R through -80R (Table 1). Seven samples were barren as a result of the complete dissolution of nannofossils. The nannofossil assemblages consist of only 28 species represented mainly by such dissolution-resistant taxa as Watznaueria barnesae and Micula decussata.

\section{Cretaceous/Tertiary Boundary}

The Cretaceous/Tertiary boundary cannot be placed reliably using calcareous nannofossils because of poor preservation of the material and the usual reworking of nannofossils across this boundary (e.g., see Pospichal and Wise, 1990). As noted by the shipboard nannofossil specialists (Kroenke, Berger, Janecek, et al., 1991, p. 400):

The wealth of small Tertiary placolith taxa (i.e., Biscutum, Cruciplacolithus, and Toweius) emerging immediately after the mass extinction of Cretaceous forms ... essentially have been dissolved in the nearest $8 \mathrm{~m}$ above the assigned $\mathrm{K} / \mathrm{T}$ boundary horizon at Site 807 . Trace amounts of such Danian placoliths, however, are consistently present from $1.1 \mathrm{~m}$ above the boundary horizon.

This indeed was essentially the case as we noted only specimens of the Tertiary Coccolithus pelagicus down to Sample 130-807C$54 \mathrm{R}-3,88 \mathrm{~cm}$ (1192.7 mbsf), and all other such taxa were absent except for the expected admixture of Cretaceous forms. Most of the material in the remainder of Core 130-807C-54R and in the top of Core $130-807 \mathrm{C}-55 \mathrm{R}$ was micrite that was essentially barren of nannofossils other than the most dissolution-resistant Cretaceous forms.

On board ship, the nannofossil $\mathrm{K} / \mathrm{T}$ boundary was placed within a 16-cm interval immediately below Sample 130-807B-54R-3, 127 $\mathrm{cm}$ (1192.9-1193.1 mbsf), which contained the only abundant occurrence of the calcareous dinoflagellate Thoracosphaera (Kroenke, Berger, Janecek, et al., 1991, p. 403, table 6). Corfield and Cartlidge (this volume), however, place it much lower, between Sections 130807B-55R-3 and -4 based on $\delta^{13} \mathrm{C}$ signatures. Specifically, they note the initiation of a rapid decline in $\delta^{13} \mathrm{C}$ values at $1202.25 \mathrm{mbsf}$ (Sample $130-807 \mathrm{C}-55 \mathrm{R}-4,85-89 \mathrm{~cm})$. Based on planktonic foraminifers viewed in thin sections of impregnated sediment, Premoli Silva (this volume) and Sliter and Leckie (this volume) place the $\mathrm{K} / \mathrm{T}$ boundary near the top of Core 55R, at 1197.2 mbsf (Sample 130-807C-55R-1, $30-31 \mathrm{~cm})$.

The presence of common Coccolithus pelagicus at $1192.7 \mathrm{mbsf}$ places an upper limit on what is designated as the " $\mathrm{K} / \mathrm{T}$ boundary interval" in Table 1. The FO of this taxon falls within Subzone CPIb, the base of which is marked by the FO of Cruciplacolithus tenuis. 
Table 1. Distribution of calcareous nannofossils in Hole 807C.

\begin{tabular}{|c|c|c|c|c|c|c|c|c|c|c|c|}
\hline Age & $\begin{array}{l}\text { Zonation } \\
\text { Tertiary: Okada and Bukry (1980) } \\
\text { Cretaceous: Thierstein (1967) and } \\
\text { Verbeek (1977) }\end{array}$ & $\begin{array}{l}\text { Lithostratigraphic } \\
\text { unit }\end{array}$ & $\begin{array}{l}\text { Core, section. } \\
\text { interval }(\mathrm{cm})\end{array}$ & $\begin{array}{l}\text { Depth } \\
\text { (mbsf) }\end{array}$ & 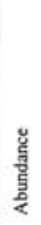 & 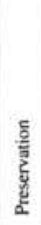 & 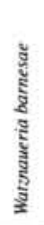 & 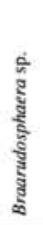 & 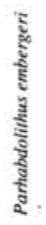 & 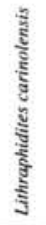 & 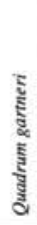 \\
\hline early Paleocene & $\begin{array}{l}\text { Cruciplacolithus temuis } \\
\text { Subzone } \\
\text { (CPIb) }\end{array}$ & \multirow{6}{*}{ IIB } & $\begin{array}{l}54 \mathrm{R}-1,125 \\
54 \mathrm{R}-2,117 \\
54 \mathrm{R}-3,88\end{array}$ & $\begin{array}{l}1190.0 \\
1191.5 \\
1192.7\end{array}$ & $\begin{array}{l}\text { A } \\
\text { C } \\
\text { C }\end{array}$ & $\begin{array}{l}\mathrm{M} \\
\mathrm{P} \\
\mathrm{P}\end{array}$ & $\begin{array}{l}\mathrm{A} \\
\mathrm{C} \\
\mathrm{C}\end{array}$ & $\dot{:}$ & $\vdots$ & $\therefore$ & F \\
\hline$K / T$ & Boundary interval & & $\begin{array}{l}54 R-4,93 \\
54 R-C C \\
5 S R-1,142 \\
55 R-2,38 \\
55 R-3,78\end{array}$ & $\begin{array}{l}1194.2 \\
1194.8 \\
1198.3 \\
1198.8 \\
1200.7\end{array}$ & $\begin{array}{l}\mathrm{C} \\
\mathrm{F} \\
\mathrm{C} \\
\mathrm{A} \\
\mathrm{A}\end{array}$ & $\begin{array}{l}\mathrm{P} \\
\mathrm{P} \\
\mathrm{M} \\
\mathrm{M} \\
\mathrm{M}\end{array}$ & $\begin{array}{l}\text { C } \\
\text { F } \\
\text { C } \\
\text { A } \\
\text { A }\end{array}$ & $\dot{\vdots}$ & $\dot{:}$ & $\vdots$ & $\begin{array}{l}\mathrm{F} \\
\mathrm{R} \\
\dot{\mathrm{R}} \\
\mathrm{F}\end{array}$ \\
\hline late late Maastrichtian & Micula munus Zone & & $\begin{array}{l}55 R-4,135 \\
55 R-C C \\
56 R-1.23 \\
56 R-2.23 \\
56 R-3.23 \\
56 R-C C \\
57 R-1.66 \\
57 R-2,66 \\
57 R-C C \\
58 R-1.7 \\
58 R-C C \\
59 R-1.66 \\
59 R-2.118 \\
59 R-C C \\
60 R-C C \\
61 R-1.56 \\
61 R-2,91 \\
61 R-C C \\
62 R-1.112\end{array}$ & $\begin{array}{l}1202.7 \\
1203.0 \\
1206.8 \\
1208.3 \\
1209.8 \\
1210.3 \\
1217.0 \\
1218.5 \\
1219.1 \\
1222.6 \\
1223.0 \\
1232.9 \\
1234.9 \\
1235.5 \\
1242.0 \\
1252.1 \\
1253.9 \\
1254.2 \\
1262.3\end{array}$ & $\begin{array}{l}\text { A } \\
\text { A } \\
A \\
A \\
A \\
C \\
A \\
A \\
A \\
A \\
A \\
A \\
A \\
A \\
A \\
A \\
A \\
A \\
A \\
A \\
A \\
A \\
A \\
A\end{array}$ & $\begin{array}{l}\mathrm{M} \\
\mathrm{M} \\
\mathrm{P} \\
\mathrm{P} \\
\mathrm{M} \\
\mathrm{M} \\
\mathrm{P} \\
\mathrm{P} \\
\mathrm{P} \\
\mathrm{M} \\
\mathrm{M} \\
\mathrm{M} \\
\mathrm{P} \\
\mathrm{P} \\
\mathrm{P} \\
\mathrm{P} \\
\mathrm{P} \\
\mathrm{P} \\
\mathrm{P}\end{array}$ & $\begin{array}{l}\mathrm{A} \\
\mathrm{C} \\
\mathrm{A} \\
\mathrm{A} \\
\mathrm{C} \\
\mathrm{A} \\
\mathrm{A} \\
\mathrm{A} \\
\mathrm{A} \\
\mathrm{A} \\
\mathrm{A} \\
\mathrm{A} \\
\mathrm{A} \\
\mathrm{A} \\
\mathrm{A} \\
\mathrm{A} \\
\mathrm{A} \\
\mathrm{A} \\
\mathrm{A} \\
\mathrm{A}\end{array}$ & $\begin{array}{l}\vdots \\
\vdots \\
\vdots \\
\vdots \\
\vdots \\
\vdots \\
\vdots\end{array}$ & $\begin{array}{l}\mathrm{R} \\
\mathrm{R} \\
\mathrm{R} \\
\\
\mathrm{R} \\
\\
\mathrm{R} \\
\mathrm{R} \\
\mathrm{F} \\
\\
\mathrm{R} \\
\mathrm{R} \\
\mathrm{F} \\
\mathrm{R} \\
\mathrm{R} \\
\mathrm{R}\end{array}$ & $\begin{array}{l}\vdots \\
\vdots \\
\vdots \\
\vdots \\
\mathrm{R} \\
\mathrm{F} \\
\mathrm{C} \\
\mathrm{C} \\
\mathrm{F} \\
\mathrm{C} \\
\mathrm{F} \\
\mathrm{F} \\
\mathrm{C}\end{array}$ & $\begin{array}{l}\mathrm{R} \\
\vdots \\
\mathrm{F} \\
\mathrm{F} \\
\mathrm{F} \\
\mathrm{F} \\
\mathrm{R} \\
\vdots \\
\mathrm{C} \\
\mathrm{C} \\
\mathrm{C} \\
\mathrm{F} \\
\mathrm{F} \\
\mathrm{C} \\
\mathrm{C}\end{array}$ \\
\hline early late Maastrichtian & $\begin{array}{l}\text { Lithrupidites quadrutus } \\
\text { Zone }\end{array}$ & & $\begin{array}{l}62 \mathrm{R}-2,67 \\
62 \mathrm{R}-3,12.3 \\
62 \mathrm{R}-4,7 \\
62 \mathrm{R}-\mathrm{CC} \\
63 \mathrm{R}-1,37 \\
63 \mathrm{R}-2,60 \\
63 \mathrm{R}-3,56 \\
63 \mathrm{R}-4,46 \\
63 \mathrm{R}-\mathrm{CC} \\
64 \mathrm{R}-1.111 \\
64 \mathrm{R}-2.107 \\
64 \mathrm{R}-3.16 \\
64 \mathrm{R}-\mathrm{CC} \\
65 \mathrm{R}-1.75 \\
65 \mathrm{R}-2,78 \\
65 \mathrm{R}-\mathrm{CC} \\
66 \mathrm{R}-1.6 \\
66 \mathrm{R}-2.6 \\
66 \mathrm{R}-3.6 \\
66 \mathrm{R}-\mathrm{CC} \\
67 \mathrm{R}-1.45 \\
67 \mathrm{R}-2,43 \\
67 \mathrm{R}-3,16 \\
67 \mathrm{R}-4.124\end{array}$ & $\begin{array}{l}1263.4 \\
1265.4 \\
1265.8 \\
1266.0 \\
1271.2 \\
1272.9 \\
1274.4 \\
1275.8 \\
1276.2 \\
1281.6 \\
1283.1 \\
1283.7 \\
1284.2 \\
1290.8 \\
1292.4 \\
1293.3 \\
1299.9 \\
1301.4 \\
1302.9 \\
1304.2 \\
1309.9 \\
1311.4 \\
1312.7 \\
1315.2\end{array}$ & $\begin{array}{l}\mathrm{A} \\
\mathrm{A} \\
\mathrm{A} \\
\mathrm{A} \\
\mathrm{A} \\
\mathrm{A} \\
\mathrm{A} \\
\mathrm{A} \\
\mathrm{A} \\
\mathrm{A} \\
\mathrm{A} \\
\mathrm{A} \\
\mathrm{A} \\
\mathrm{A} \\
\mathrm{A} \\
\mathrm{A} \\
\mathrm{A} \\
\mathrm{A} \\
\mathrm{A} \\
\mathrm{A} \\
\mathrm{A} \\
\mathrm{A} \\
\mathrm{A} \\
\mathrm{A} \\
\mathrm{A} \\
\mathrm{A}\end{array}$ & $\begin{array}{l}\mathrm{P} \\
\mathrm{P} \\
\mathrm{P} \\
\mathrm{P} \\
\mathrm{P} \\
\mathrm{M} \\
\mathrm{P} \\
\mathrm{P} \\
\mathrm{P} \\
\mathrm{P} \\
\mathrm{P} \\
\mathrm{P} \\
\mathrm{P} \\
\mathrm{P} \\
\mathrm{P} \\
\mathrm{P} \\
\mathrm{P} \\
\mathrm{P} \\
\mathrm{M} \\
\mathrm{M} \\
\mathrm{P} \\
\mathrm{P} \\
\mathrm{P} \\
\mathrm{P}\end{array}$ & $\begin{array}{l}\mathrm{A} \\
\mathrm{A} \\
\mathrm{A} \\
\mathrm{A} \\
\mathrm{A} \\
\mathrm{A} \\
\mathrm{A} \\
\mathrm{A} \\
\mathrm{A} \\
\mathrm{A} \\
\mathrm{A} \\
\mathrm{A} \\
\mathrm{A} \\
\mathrm{A} \\
\mathrm{A} \\
\mathrm{A} \\
\mathrm{A} \\
\mathrm{A} \\
\mathrm{A} \\
\mathrm{A} \\
\mathrm{A} \\
\mathrm{A} \\
\mathrm{A} \\
\mathrm{A}\end{array}$ & $\begin{array}{l}\vdots \\
\vdots \\
\vdots \\
\vdots \\
\vdots \\
\vdots \\
\vdots \\
\vdots \\
\vdots \\
\vdots\end{array}$ & $\begin{array}{l}\mathbf{R} \\
\mathbf{R} \\
\vdots \\
\mathbf{R} \\
\vdots \\
\vdots \\
\vdots \\
\vdots \\
\vdots \\
\vdots \\
\vdots \\
\vdots \\
\vdots\end{array}$ & $\begin{array}{l}\mathrm{C} \\
\mathrm{F} \\
\mathrm{C} \\
\mathrm{F} \\
\mathrm{F} \\
\mathrm{F} \\
\mathrm{F} \\
\mathrm{F} \\
\mathrm{F} \\
\mathrm{F} \\
\mathrm{R} \\
\mathrm{A} \\
\mathrm{F} \\
\mathrm{F} \\
\mathrm{C} \\
\vdots \\
\vdots \\
\vdots\end{array}$ & $\begin{array}{l}\mathrm{C} \\
\mathrm{C} \\
\mathrm{C} \\
\mathrm{C} \\
\mathrm{C} \\
\mathrm{F} \\
\mathrm{F} \\
\mathrm{C} \\
\mathrm{C} \\
\mathrm{C} \\
\mathrm{C} \\
\mathrm{C} \\
\mathrm{C} \\
\mathrm{F} \\
\mathrm{C} \\
\mathrm{C} \\
\mathrm{C} \\
\mathrm{C} \\
\mathrm{C} \\
\mathrm{C} \\
\mathrm{C} \\
\mathrm{C} \\
\mathrm{C} \\
\mathrm{C}\end{array}$ \\
\hline $\begin{array}{l}\text { early Maastrichtian- } \\
\text { late late Campanian }\end{array}$ & $\begin{array}{c}\text { Quadrum gothicum } \\
\text { Zone? }\end{array}$ & & $\begin{array}{l}67 R-5,48 \\
67 R-C C \\
68 R-1,54 \\
68 R-2,82 \\
68 R-3,41 \\
68 R-C C \\
69 R-1,133 \\
69 R-2,105 \\
69 R-3,60 \\
69 R-4,65 \\
69 R-5,69 \\
69 R-C C \\
70 R-1,96 \\
70 R-2,38 \\
70 R-3,99\end{array}$ & $\begin{array}{l}1316.0 \\
1316.4 \\
1319.6 \\
1321.4 \\
1322.5 \\
1322.7 \\
1330.1 \\
1331.3 \\
1332.4 \\
1333.9 \\
1335.5 \\
1335.7 \\
1339.4 \\
1340.3 \\
1342.4\end{array}$ & $\begin{array}{l}\text { A } \\
A \\
A \\
A \\
A \\
A \\
A \\
A \\
A \\
A \\
A \\
A \\
A \\
A \\
A \\
A \\
A \\
A\end{array}$ & $\begin{array}{l}\mathrm{P} \\
\mathrm{P} \\
\mathrm{P} \\
\mathrm{P} \\
\mathrm{P} \\
\mathrm{P} \\
\mathrm{P} \\
\mathrm{P} \\
\mathrm{P} \\
\mathrm{P} \\
\mathrm{P} \\
\mathrm{P} \\
\mathrm{P} \\
\mathrm{P}\end{array}$ & 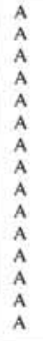 & $\begin{array}{l}\vdots \\
\vdots \\
\vdots \\
\vdots \\
\vdots\end{array}$ & $\begin{array}{l}: \\
\vdots \\
\vdots \\
\vdots \\
\vdots\end{array}$ & $\begin{array}{l}\text { F } \\
\\
F \\
F \\
F \\
F \\
F \\
F \\
F \\
C \\
C\end{array}$ & $\begin{array}{l}\mathrm{C} \\
\mathrm{C} \\
\mathrm{C} \\
\mathrm{C} \\
\mathrm{C} \\
\mathrm{C} \\
\mathrm{C} \\
\mathrm{C} \\
\mathrm{C} \\
\mathrm{C} \\
\mathrm{C} \\
\mathrm{C} \\
\mathrm{C} \\
\mathrm{C} \\
\mathrm{C}\end{array}$ \\
\hline carly late Campanian & $\begin{array}{l}\text { Quadrum trifidum } \\
\text { Zone }\end{array}$ & & $\begin{array}{l}70 R-4,64 \\
70 R-C C \\
7 I R-1.116 \\
7 I R-2,106 \\
7 I R-3.95\end{array}$ & $\begin{array}{l}1343.5 \\
1344.7 \\
1349.2 \\
1350.6 \\
1351.9\end{array}$ & $\begin{array}{l}\mathrm{A} \\
\mathrm{C} \\
\mathrm{A} \\
\mathrm{C} \\
\mathrm{R}\end{array}$ & $\begin{array}{l}\mathrm{P} \\
\mathrm{P} \\
\mathrm{P} \\
\mathrm{P} \\
\mathrm{P}\end{array}$ & $\begin{array}{l}\mathrm{A} \\
\mathrm{C} \\
\mathrm{A} \\
\mathrm{C}\end{array}$ & $\therefore$ & $\therefore$ & F & $\begin{array}{l}\mathrm{C} \\
\mathrm{C} \\
\mathrm{C} \\
\mathrm{C}\end{array}$ \\
\hline$?$ & $?$ & IIIA & $\begin{array}{l}72 \mathrm{R}-1,95 \\
72 \mathrm{R}-2,99 \\
72 \mathrm{R}-3.2\end{array}$ & $\begin{array}{l}1358.6 \\
1360.2 \\
1360.7\end{array}$ & $\begin{array}{l}\mathrm{R} \\
\mathrm{R} \\
\mathrm{R}\end{array}$ & $\begin{array}{l}\mathrm{P} \\
\mathrm{P} \\
\mathrm{P}\end{array}$ & $\begin{array}{l}R \\
R \\
R\end{array}$ & $\therefore$ & & $\dot{;}$ & R \\
\hline \multirow{2}{*}{$\begin{array}{l}\text { early Aptian } \\
\text { (Sliter, this volume) }\end{array}$} & \multirow[b]{2}{*}{$?$} & \multirow[t]{2}{*}{ IIIB } & $\begin{array}{l}73 \mathrm{R}-2.90 \\
74 \mathrm{R}, \text { top }\end{array}$ & $\begin{array}{l}1369.8 \\
1375.4\end{array}$ & $\begin{array}{l}\text { C } \\
\text { A }\end{array}$ & $\begin{array}{l}\mathrm{P} \\
\mathrm{P}\end{array}$ & $\begin{array}{l}\text { C } \\
\text { A }\end{array}$ & $\begin{array}{l}\mathrm{R} \\
\mathrm{R}\end{array}$ & $\begin{array}{l}\mathrm{F} \\
\mathrm{F}\end{array}$ & $\mathrm{F}$ & : \\
\hline & & & $\begin{array}{l}80 \mathrm{R}-1,77 \\
80 \mathrm{R}-3,75\end{array}$ & $\begin{array}{l}1424.7 \\
1427.6\end{array}$ & $\begin{array}{l}\mathrm{C} \\
\mathrm{R}\end{array}$ & $\begin{array}{l}\mathrm{P} \\
\mathrm{P}\end{array}$ & $\begin{array}{l}\mathrm{C} \\
\mathrm{R}\end{array}$ & $\therefore$ & $\therefore$ & : & : \\
\hline
\end{tabular}

Note: For abundance and preservation: $\mathrm{A}=$ abundant, $\mathrm{C}=$ common, $\mathrm{F}=$ few, $\mathrm{R}=$ rare, $\mathrm{M}=$ moderate, and $\mathrm{P}=$ poor. 
MESOZOIC CALCAREOUS NANNOFOSSILS

Table 1 (continued).

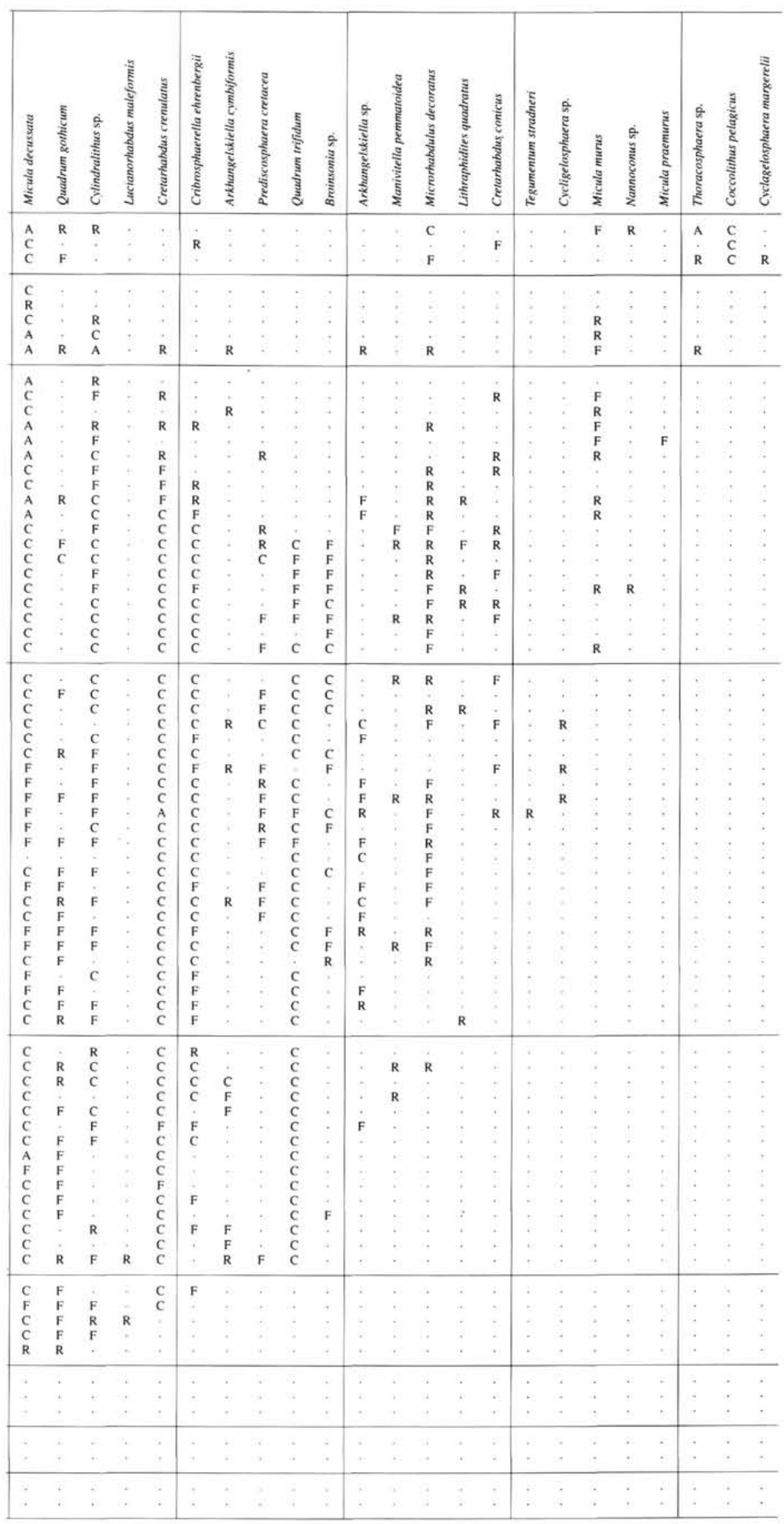

87 
Because of the poor preservation, we were not able to distinguish $C$. tenuis in our samples. At a number of ODP sites studied recently by J. Pospichal, the first common $C$. pelagicus (referred to by Pospichal as $C$. cavus) occurs about $1 \mathrm{~m}$ above the FAD of $C$. tenuis (e.g., ODP Site 752, Pospichal, 1991, table 1; ODP Site 738, J. Pospichal, pers. comm., 1992; DSDP Site 738, J. Pospichal, pers. comm., 1992).

According to the time scale of Berggren et al. (1985), the FAD of Cruciplacolithus tenuis is dated at $65.9 \mathrm{Ma}, 500 \mathrm{k} . \mathrm{y}$. above the $\mathrm{K} / \mathrm{T}$ boundary at $66.4 \mathrm{Ma}$. The Thoracosphaera acme noted aboard ship occurs about $40 \mathrm{~cm}$ below the FO of Coccolithus pelagicus, but well above the $\mathrm{K} / \mathrm{T}$ boundary indicated by planktonic foraminifers (Sample 130-807C-55R-1, 30-31 cm; $1197.2 \mathrm{mbsf}$ ) and carbon isotopes (Sample 130-807C-55R-4, 85-89 cm; $1202.2 \mathrm{mbsf}$ ) (Sliter and Leckie, this volume; Corfield and Cartlidge (this volume). The level of the Thoracosphaera acme is consistent with its position at several other (but not all) ODP sites studied by Pospichal (e.g., ODP Site 690 , where it is distinctly above the $\mathrm{K} / \mathrm{T}$ boundary [Pospichal and Wise, 1990]),

The exact stratigraphic distance between the thoracosphaerid acme and the $\mathrm{K} / \mathrm{T}$ boundaries determined from planktonic foraminifers or carbon isotopes cannot be ascertained because the recovery in Core $130-807 \mathrm{C}-54 \mathrm{R}$ was only $6.0 \mathrm{~m}$ or $74.1 \%$, of the $8.1-\mathrm{m}$ interval cored. Although by ODP convention all recovered material is measured from the top of the drilled interval, no way exists to know exactly where a given sample was cored as core loss could have occurred anywhere within the interval. Maximum and minimum limits can be determined, however, depending on the amount of material recovered and the position of a given sample within that recovered material. Thus, the thoracosphaerid acme in Sample 130-807C-54R-3, $127 \mathrm{~cm}$, could lie as little as $2.0 \mathrm{~m}$ or as much as $3.3 \mathrm{~m}$ above the foraminiferal $\mathrm{K} / \mathrm{T}$ boundary, whereas it could have come from 7.0 to $8.3 \mathrm{~m}$ above the carbon isotope $\mathrm{K} / \mathrm{T}$ boundary.

\section{Upper Cretaceous}

\section{Micula murus Zone}

The base of this uppermost Maastrichtian zone is defined by the first occurrence of Micula murus in Sample 130-807C-62R-1, 112 $\mathrm{cm}$, and the top of the zone by the nannofossil $\mathrm{K} / \mathrm{T}$ boundary. Watznaueria barnesae and Micula decussata are dominant and continuously present whereas Cretarhabdus crenulatus, Microrhabdulus decoratus, Quadrum gartneri, and Cylindralithus sp. are common and frequently present in the assemblages. Lithraphidites carniolensis, Prediscosphaera cretacea, Quadrum trifidum, and a small form $(6-8 \mu \mathrm{m})$ of Broinsonia have their last occurrence (LO) in the lower part of the zone whereas Arkhangelskiella cymbiformis, Cretarhabdus crenulatus, Cribrosphaerella ehrenbergii, and Parhabdolithus embergeri disappear in the upper part of the zone. The zone corresponds to Zone NC23 of Roth (1978).

\section{Lithrapidites quadratus Zone}

This mid-Maastrichtian zone is delimited by the FO of Lithrapidites quadratus from Sample 130-807C-67R-4, $124 \mathrm{~cm}$, and the FO of Micula murus in Sample 130-807C-62R-1, $112 \mathrm{~cm}$. Specimens of $L$. quadratus are rare and were found only in two samples. Nannofossils in this zone are most abundant and also diverse with a total of 19 species, 18 of which are shared with the zone above. Fossil preservation, however, remains as poor as in the zones above and below. Cretarhabdus crenulatus, C. ehrenbergii, Micula decussata, and Quadrum gartneri are continuously present, and Arkhangelskiella sp., Cylindralithus sp., L. carinolensis, $M$. decoratus, $P$. cretacea, and $Q$. gothicum are common and occur frequently in the zone. This zone is equivalent to Zone NC22 of Roth (1978).
Quadrum trifidum Zone

The base of this lower Maastrichtian to uppermost Campanian Zone is delineated by the FO of Quadrum trifidum in Sample 130$807 \mathrm{C}-70 \mathrm{R}-3,99 \mathrm{~cm}$, and its top by the FO of Lithrapidites quadratus. Heavily overgrown $Q$. trifidum with short rays are common and continuously present in the zone. In addition, $C$. crenulatus and Quadrum gartneri occur throughout the zone, but we did not observe Ceratolithoides aculeus as noted by the shipboard scientists. This zone is equivalent to Zones NC21 and NC22 of Roth (1978).

\section{Quadrum gothicum Zone?}

The presence of this upper Campanian zone is questionable as preservation in the section deteriorated further below Sample 130$807 \mathrm{C}-70 \mathrm{R}-3,99 \mathrm{~cm}$. The base of this zone was placed at Sample 130-807C-71R-3, $95 \mathrm{~cm}$, based on the presence of Quadrum gothicum and the absence of $Q$. trifidum. Shipboard scientists, however, traced $Q$. trifidum further down into the section than we did (to Sample 130-807C-71R-1, 37-38 cm; Kroenke, Berger, Janecek, et al., 1991, p. 401),

Abundance and species diversity in this zone decreases dramatically to only nine species. Beside the most dissolution-resistant species such as $W$. barnesae and $M$. decussata, specimens of $C$. crenulatus, $C$. ehrenbergii, L. carniolensis, Lucianorhabdus maleformis, $Q$. gothicum, and Cylindralithus sp. are noted. The zone is recognized by Verbeek (1977) and Sissingh (1977), but not by Roth (1978).

\section{Lower Cretaceous}

Samples below Core 130-807C-72R yielded no diagnostic nannofossils. This sequence, which includes samples in Core 130-807C$80 \mathrm{R}$ taken between basalt flows, is best described by the shipboard nannofossil specialists (Kroenke, Berger, Janecek, et al., 1991, pp. 401-402). Premoli Silva (this volume) and Sliter and Leckie (this volume) assign an age of early Aptian to Sample 130-807C-74R-1, $24 \mathrm{~cm}$, taken directly above basement.

\section{Hole 803D}

Hole $803 \mathrm{D}$ was drilled at $2^{\circ} 25.98^{\prime} \mathrm{N}, 160^{\circ} 32.46^{\prime} \mathrm{E}$ in a water depth of $3414.2 \mathrm{~m}$. We were provided five widely spaced samples from this site across the $\mathrm{K} / \mathrm{T}$ boundary (Table 2); however, assemblages in about 40 smear slides were examined by the shipboard nannofossil specialists, who provide detailed explanations and a range chart for 17 closely spaced samples across the boundary (Kroenke, Berger, Janecek, et al., 1991, p. 122, table 4). These specialists place the $\mathrm{K} / \mathrm{T}$ boundary at this locality in Section 130-803C-68R-1, between 38 and $53 \mathrm{~cm}$, based on an abundance increase in Thoracosphaera spp. We confirm in Sample 130-803D-68R-1, 54-55 cm, the presence of Micula prinsii, an uppermost Maastrichtian marker noted by PerchNielsen (1979). Below that, Cretaceous nannofossils are essentially absent in our samples.

\section{ACKNOWLEDGMENTS}

We thank James J. Pospichal for helpful discussion and David Bukry and Wuchang Wei for critical reviews. Laboratory support was provided by National Science Foundation grant DPP-9118480.

\section{REFERENCES}

Hay, W.W., 1970. Calcareous nannofossils from cores recovered on Leg 4. In Bader, R.G., Gerard, R.D., et al., Init. Repts. DSDP, 4: Washington (U.S. Govt. Printing Office), 723-501. 
Kroenke, L.W., Berger, W.H., Janecek, T.R., et al., 1991. Proc. ODP, Init. Repts., 130: College Station, TX (Ocean Drilling Program).

Okada, H., and Bukry, D., 1980. Supplementary modification and introduction of code numbers to the low-latitude coccolith biostratigraphic zonation (Bukry, 1973, 1975). Mar. Micropaleontol., 5:321-325.

Perch-Nielsen, K., 1979. Calcareous nannofossils from the Cretaceous between the North Sea and the Mediterranean. In Wiedman, J. (Ed.), Aspekte der Kreide Europas. Int. Union Geol. Sci. Ser. A, 6:223-272.

, 1985a. Cenozoic calcareous nannofossils. In Bolli, H.M., Saunders, J.B., and Perch-Nielsen, K. (Eds.), Plankton Stratigraphy: Cambridge (Cambridge Univ. Press), 427-554.

, 1985b. Mesozoic calcareous nannofossils. In Bolli, H.M., Saunders, J.B., and Perch-Nielsen, K. (Eds.), Plankton Stratigraphy: Cambridge (Cambridge Univ. Press), 329-426.

Pospichal, J.J., 1991. Calcareous nannofossils across Cretaceous/Tertiary boundary at Site 752, Eastern Indian Ocean. In Weissel, J., Peirce, J., Taylor, E., Alt, J., et al., 1991. Proc. ODP, Sci. Results, 121: College Station, TX (Ocean Drilling Program), 395-414.

Pospichal, J.J., and Wise, S.W., Jr., 1990. Calcareous nannofossils across the K/T boundary, ODP Hole 690C, Maud Rise, Weddell Sea. In Barker, P.F., Kennett, J.P., et al., Proc. ODP, Sci. Results, 113: College Station, TX (Ocean Drilling Program), 515-532.

Roth, P.H., 1978. Cretaceous nannoplankton biostratigraphy and oceanography of the northwestern Atlantic Ocean. In Benson, W.E., Sheridan, R.E., et al., Init. Repts. DSDP, 44: Washington (U.S. Govt. Printing Office), 731-759.

Sissingh, W., 1977. Biostratigraphy of Cretaceous calcareous nannoplankton. Geol. Mijnbouw, 56:37-65.

Thierstein, H.R., 1976. Mesozoic calcareous nannoplankton biostratigraphy of marine sediments. Mar. Micropaleontol., 1:325-362.

Verbeek, J.W., 1977. Upper Cretaceous nannoplankton zonation in a composite section near El Kef, Tunisia. Proc. Kon. Ned. Akad. Wetensch., B79:129-148.

Date of initial receipt: 6 December 1991

Date of acceptance: 23 June 1992

Ms 130B-054

\section{APPENDIX}

Calcareous Nannofossils Considered in this Report in Alphabetical Order of Generic Epithets

Arkhangelskiella cymbiformis Vekshina, 1959

Braarudosphaera sp.

Broinsonia sp.

Coccolithus pelagicus (Wallich, 1877) Schiller, 1930

Cretarhabdus conicus Bramlette and Martini, 1964

Cretarhabdus crenulatus Bramlette and Martini, 1964

Cribrosphaerella ehrenbergii (Arkhangelsky) Deflandre in Piveteau, 1952

Cruciplacolithus tenuis (Stradner, 1961) Hay and Mohler in Hay et al., 1967

Cyclagelosphaera margerelii Noël, 1965

Cyclagelosphaera sp.

Cyclicargolithus floridanus (Roth and Hay in Hay et al. 1967) Bukry, 1971

Cylindralithus sp.

Lithraphidites carniolensis Deflandre, 1963

Lithraphidites quadratus Bramlette and Martini, 1964

Lucianorhabdus maleformis Reinhardt, 1966

Manivitella pemmatoidea (Deflandre in Manivit, 1965) Thierstein, 1971

Microrhabdulus decoratus Deflandre, 1959

Micula decussata Vekshina, 1959

Micula murus (Martini, 1961) Bukry, 1973

Micula praemurus (Bukry, 1973) Stradner and Steinmetz, 1984

Nannoconus sp.

Parhabdolithus embergeri (Noël, 1975) Stradner, 1963

Prediscosphaera cretacea (Arkhangelsky) Gartner, 1968

Prinsius africanus Perch-Nielsen, 1980

Quadrum gartneri Prins and Perch-Nielsen in Manivit et al., 1977

Quadrum gothicum (Deflandre, 1959) Prins and Perch-Nielsen in Manivit et al., 1977

Quadrum trifidum (Stradner in Stradner and Papp, 1961) Prins and Perch-Nielsen in Manivit et al., 1977

Quadrum sissinghii Perch-Nielsen, 1984

Tegumentum stradneri Thierstein in Roth and Thierstein, 1972

Thoracosphaera sp.

Watznaueria barnesae (Black) Perch-Nielsen, 1968 


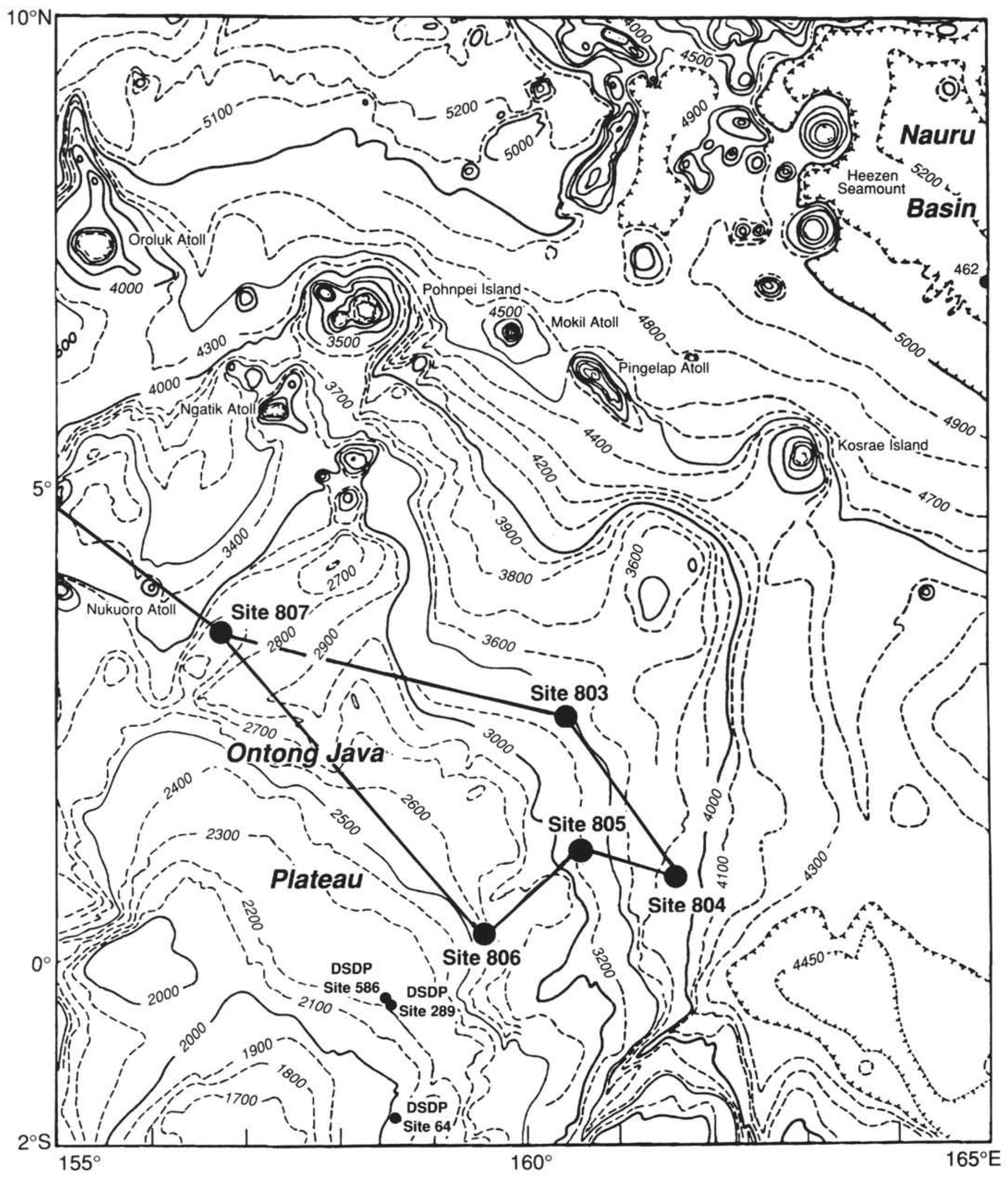

Figure 1. Location of Sites 803 and 807. 
Table 2. Distribution of calcareous nannofossils in Hole 803D.

\begin{tabular}{|c|c|c|c|c|c|c|c|c|c|c|c|c|c|c|c|c|}
\hline Age & $\begin{array}{c}\text { Zonation } \\
\text { Thierstein (1967) and } \\
\text { Verbeek (1977) }\end{array}$ & Abundance & Preservation & $\begin{array}{l}\text { Core, section, } \\
\text { interval }(\mathrm{cm})\end{array}$ & 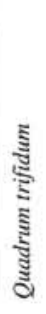 & 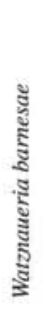 & 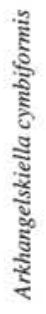 & 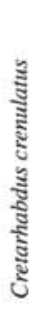 & 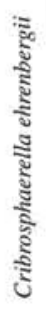 & 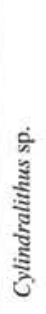 & 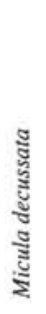 & 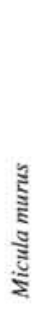 & 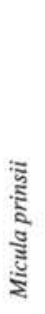 & 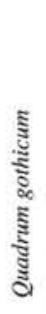 & 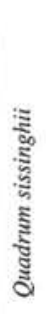 & 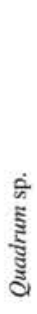 \\
\hline Eocene & & & & $\begin{array}{l}67 \mathrm{R}-1,26-27 \\
67 \mathrm{R}-2,26-27\end{array}$ & $\dot{.}$ & $\dot{r}$ & . & $\dot{.}$ & $\dot{.}$ & $\dot{.}$ & $\dot{.}$ & $\dot{.}$ & $\dot{.}$ & . & •. & $\dot{.}$ \\
\hline $\begin{array}{c}\text { late late } \\
\text { Maastrichtian }\end{array}$ & $\begin{array}{c}\text { Micula murus } \\
\text { Zone }\end{array}$ & $\begin{array}{l}\mathrm{A} \\
\mathrm{C} \\
\mathrm{R}\end{array}$ & $\begin{array}{l}\mathrm{P} \\
\mathrm{P} \\
\mathrm{P}\end{array}$ & $\begin{array}{l}68 \mathrm{R}-1,54-55 \\
68 \mathrm{R}-2,82-83 \\
68 \mathrm{R}-3,56-61\end{array}$ & F & $\begin{array}{l}\mathrm{A} \\
\mathrm{C} \\
\mathrm{R}\end{array}$ & F & $\begin{array}{l}\mathrm{C} \\
:\end{array}$ & F & $\begin{array}{l}\mathrm{F} \\
\dot{ }\end{array}$ & $\begin{array}{l}\mathrm{C} \\
\dot{ }\end{array}$ & $\begin{array}{l}\mathrm{C} \\
\vdots \\
.\end{array}$ & $\begin{array}{l}\mathrm{R} \\
\dot{ }\end{array}$ & $\begin{array}{l}\mathrm{F} \\
\dot{ }\end{array}$ & $\begin{array}{l}\mathrm{F} \\
\cdot\end{array}$ & $\begin{array}{l}\mathrm{R} \\
\text {. }\end{array}$ \\
\hline
\end{tabular}



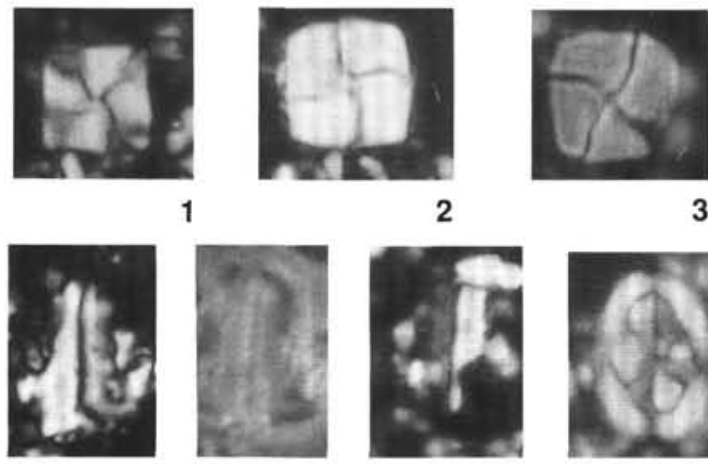

7

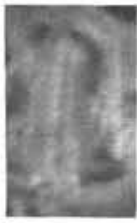

8

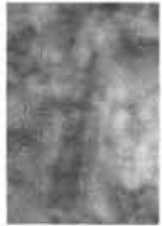

14

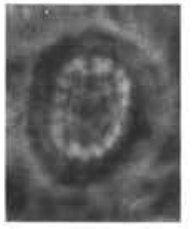

21
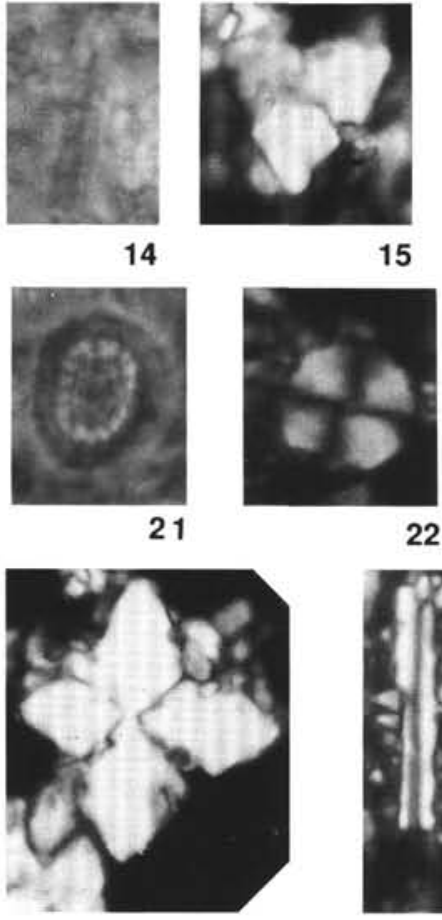

27

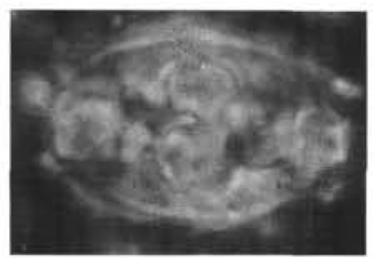

32
15

22

2

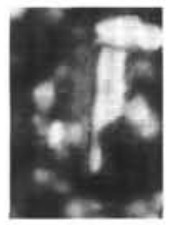

9

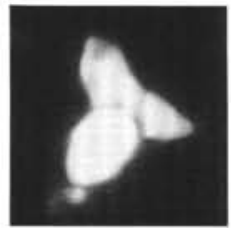

16

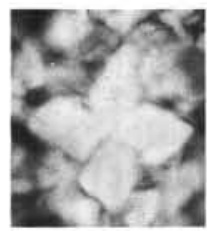

23

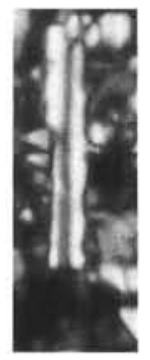

28

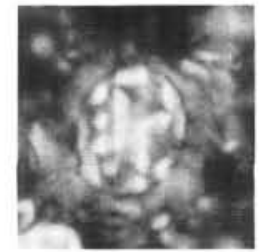

33

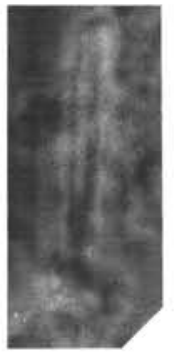

29
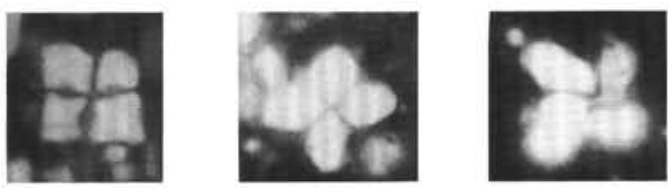

5

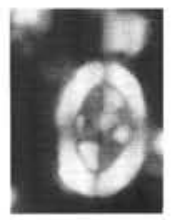

11

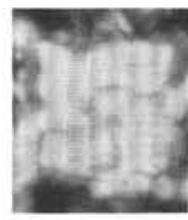

12

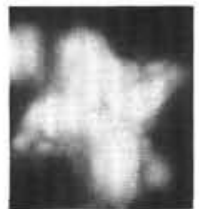

10
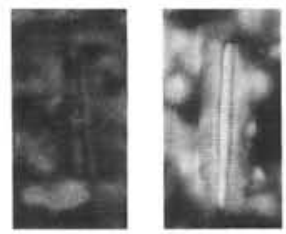

17

18
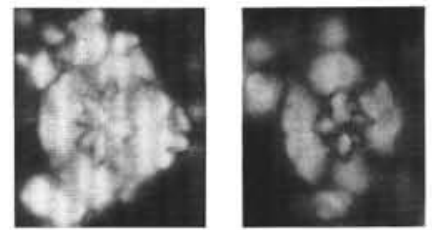

19
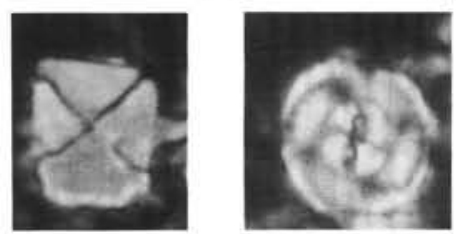

24

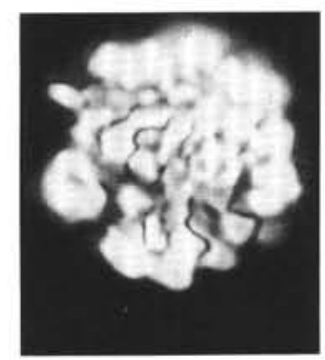

30

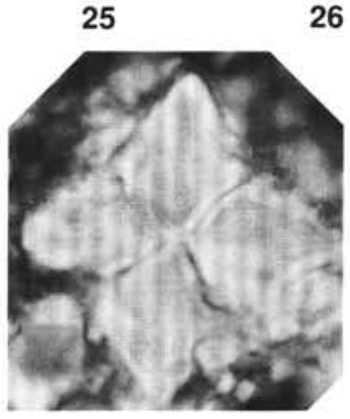

31

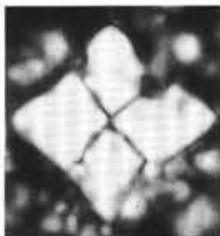

34

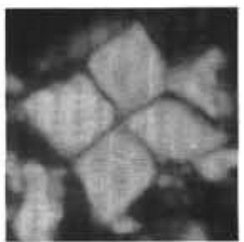

35

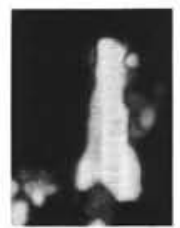

26

13

20

Plate 1. Note: All figures are light photomicrographs, $\times 2100 . \mathrm{PH}=$ phase contrast light; all other figures in cross-polarized light. 1. Micula decussata, Sample 130-807C-56R-2, 23-25 cm. 2, 4. Quadrum gartneri; (2) Sample 130-807C-56R-3, 23-25 cm; (4) Section 130-807C-56R-CC. 3. Micula praemurus, Sample 130-807C-56R-3, 23-25 cm. 5. Quadrum gothicum, Sample 130-803D-68R-1, 54-55 cm. 6. Micula murus, Sample 130-803D-68R-1, 54-55 cm. 7, 8. Lucianorhabdus maleformis, Sample 130-807C-70R-3, 99-100 cm; (8) PH. 9, 18. Lithraphidites quadratus; (9) Sample 130-807C-59R-1, 66-68 cm; (18) Sample 130-807C-62R-4, 7-8 cm. 10. Arkhangelskiella cymbiformis, Section 130-807C-57R-CC. 11. Broinsonia sp., Sample 130-807C-59R-1, 66-68 cm. 12. Micula murus, Sample 130-807C-56R-2, 23-25 cm. 13. Quadrum sissinghii, Sample 130-803D-68R-1, 54-55 cm. 14. Microrhabdulus decoratus, Sample 130-807C-62R4,7-8cm, PH. 15,16. Quadrum trifidum, (15) Sample 130-807C-67R-3, 16-18cm;(16) Sample 130-803D-68R-1,54-55 cm. 17,28, 29. Lithraphidites carniolensis; (17) Section 130-807C-62R-CC, PH; (28) Sample 130-807C-63R-4, 46-48 cm, (29) Sample 130-807C-63R-4, $46-48 \mathrm{~cm}$. 19. Cretarhabdus crenulatus, Section 130-807C-61R-CC. 20. Cretarhabdus conicus, Sample 130-807C-59R-1, 66-68 cm. 21. Cribrosphaerella ehrenbergii, Section 130-807C-61R-CC. 22. Watznaueria barnesae, Sample 130-807C-55R-3, 78-80 cm. 23, 27, 31, 34-36. Quadrum gothicum; (23) Sample 130-807C-66R-3, 6-8 cm; (27) Sample 130-807C70R-4, 64-66 cm; (31) Sample 130-807C-69R-2, 105-106 cm; (34) Sample 130-807C-66R-3, 6-8 cm; (35) Sample 130-807C-69R-5, 69-70 cm; (36) Sample 130-807C-65R-1, 75-76 cm, PH. 24. Micula sp., Sample 130-807C-62R-1, 112-113 cm. 25. Cylindralithus sp., Sample 130-807C-55R-1, 142-143 cm. 26. Ceratolitoides aculeus?, Sample 130-807C-69R-5, 69-70 cm. 30. Thoracosphaera sp., Sample 130-807C-67R-1,45-46 cm. 32. Parhabdolithus embergeri, Section 130-807C-60R-CC. 33. Prediscosphaera cretacea, Sample 130-807C-62R-1, 112-114 cm. 